\title{
Multidimensional Assessment Model of Social Intervention and Bullying Behavior to Improve Mental Health in Madrasah Aliyah (MAN) Malang Raya
}

\author{
Tristiadi Ardi Ardani' ${ }^{1}$ Fattah Hanurawan ${ }^{2}$, Carolina L.Radjah $^{3}$, Triyono ${ }^{4}$, Rohimi Zam-Zam ${ }^{5}$ \\ ${ }^{1,3,4}$ Faculty of Education, Universitas Negeri Malang, Indonesia, Faculty of Psychology of the State Islamic University (UIN), \\ Maulana Malik Ibrahim Malang, Indonesia \\ ${ }^{2}$ FakultasPendidikanPsikologi (FPPsi), Universitas Negeri Malang, Indonesia \\ ${ }^{5}$ Universitas Muhammadiyah Jakarta \\ ${ }^{1}$ tristiadi.ardi.181119@students.um.ac.id, ${ }^{2}$ Fattah.hanurawan.fppsi@um.ac.id, ${ }^{3}$ carolina.ligya.fip@um.ac.id, \\ ${ }^{4}$ triyono.fip@um.ac.id, ${ }^{5}$ Rohimi.zamzam@umj.ac.id
}

\begin{abstract}
This article discusses about bullying. Bullying behavior need to be done through a multidimensional assessment and social intervention. This model has three components, namely the five traits of behavior definition bullying, four kinds of behavior bullying, the three main groups involved in the behavior ofbul lying. This paper presents a preventive program try against bullying behavior in schools a mentioned as Citizens'Responsibility p control rogram. This approach to reintegrate pupils who had blundered into the school community in order to become disciples who have durability, as well as being a member of the school community who obediently and cling to rules and values which apply into program interventions social thereby increasing their mental health.
\end{abstract}

Keywords

A sesmen; intervention social; bullying; mental health; Madrasah Aliyah (MAN)

Article Received: 10 August 2020, Revised: 25 October 2020, Accepted: 18 November 2020

\section{Background Problem}

Education is the teaching and learning process that can produce the expected behavior changes. Not all behavior comes from yourself and innately human, but there are some behaviors that are the result of a learning process. One of the factors that affect behavior are the school environment. Therefore the school has a big responsibility in order to form a good student learning behavior. Education is closely associated with the school. School is a place of study. In the school environment is certainly as teachers and parents certainly never saw action encourages a child so that his friend has been dropped, or the activities of a child seize toys from his friend's hand.

Yet another View, a bunch of kids to laugh at and make fun of a child with ridicule or designation that is insulting. Those events can be found on the school grounds, outside the school fence (the journey from home to school and vice versa), the environment of the place of residence, or where children play. Action encouraging friends, seize toy friends, poke or mocking, impressed because common, however unconscious, the practice of bullying has occurred. Fenoena bullying in schools is nothing new, but until now has not really got special attention and dealt with seriously. Whereas, bullying is the embryo of the violence (Arya, 2018).

\section{The Study of Bullying}

Other Bullying or perundungan (KBBI online, 2017) that is disturbing; harass constantly; trouble and hurt people physically and emotionally in the form of verbal violence, physical and social, repeatedly and from time to time, like calling someone's name with the nickname, hitting, pushing, spreading rumors, threatening, or merorngrong someone. Bullying is an ongoing abuse of power in a relationship, through verbal, physical, and/or recurring social, which led to the loss of physical and/or psychological (Muliani, 2018). Bullying is negative and agesif behavior of 
a person or group of people are repeated that menylahgunakan strength imbalances with the aim of hurting the target (victim) mentally and physically (Wiyani, 2014).

\section{Forms of Bullying}

Andri Priyatna (2010:3) that several forms of bullying are:

a. physical barriers, such as: hitting, kicking, pushing, damaging the objects belonging to the victims including the Act of theft and others.

b. Verbal, such as: make fun of the name calls, harassing, threatening, frightening appearance, and others.

c. Social, such as: spreading gossip, rumor, humiliated in public, was expelled from the Association, or trap a person, so he's accused of committing such acts.

d. Cyber or electronic, such as: embarrass people by spreadingrumors on the internet social networking (e.g., facebook or MySpace), personal photo spreads.

It is expressed by Andri Priyatna, according to Amini Sejiwa Foundation (2008:2) forms of bullying include:

a. Bullying physically, this is the kind of bullying that is visible. Anyone cansee it due to physical touch between the perpetrators of bullying and its victims. Examples of physical bullying include: Slapping, foot stomping, menimpuk, menjegal, spit on, memalak, throws things, punishes with roving ran field, punishes by means of push ups, refused.

b. Bullying verbal, this type of bullying that can also be caught withour sense of hearing. Examples of verbal bullying : Cursing,

insulting, dub, shouted at, humiliated in public, accusing, cheer, spreading gossip, slander, refused.

Mental / psychological bullying, this type of bullying is the most dangerous because it does not catch the eye or ear. This practice of bullying occurs secretly and is outside the monitoring radar. Examples are: Look cynically, look full of threats, publicly humiliate, silence, isolate, humiliate, terrorize through cell phone short messages or e-mail, look at the condescending, glaring, pouting.

\section{Factors Causing Bullying}

There are many factors that cause bullying. These factors can be from the perpetrators or victims of bullying. Ponny Retno Astuti (2008: 4) explained several factors causing bullying are:

a. Economic inequality. Those who are rich usually tend to form genks whose members are from the bourgeoisie. The bourgeois group will oppress those who are considered poor.

b. Seniority Tradition. Seniority is often used as a venue for revenge for perpetrators of bullying for the uncomfortable acts he had felt when he was a junior. In addition, seniors tend to feel stronger and more powerful in school than juniors so they do what they want so that juniors respect him.

c. Families that don't get along well. If there is no harmony in the family, then the child will not feel peace. His bad experiences at home can be brought to his promiscuity with his friends.

d. Looking for popularity. The bullying person will feel happy if he is famous among his friends. That indicates that he is has more power than his friends who are victims of bullying.

According to the Sejiwa Amini Foundation (2008: 14) some of the factors causing bullying are:

a. Self satisfaction. A bullying person will feel satisfied and proud if he can "power" among his peers. With his power he will get a "label" how strong he is because he can bullying other people. And this will make it popular with his friends.

b. Lack of education in empathy for others. As a result of the lack of empathy for the perpetrators, the perpetrators of bullying tend to have high self-confidence to continually oppress their victims. They seemed unable to feel the feelings of their victims being mistreated.

c. No friends. Because they do not have friends and are afraid of being victims of bullying, bullying usually takes the initiative to oppress their friends first so that they are famous and have followers so that they will not be targeted by others.

d. Revenge. Someone who had experienced bullying tends to be doing the bullying is also on 
others who are considered weak. She tried looking pelampiasaan up persecution against him.

Similarly, presented by Andri Priyatna (2010:80), most of Researchers agree that bullying behavior has some characteristicsamong other things:

a. The existence of a gap to "hurt" the victim, both physically and verbally.

b. The presence of repetition, does not happen by accident or just occur just once.

c. The existence of an imbalance of power between the perpetrators and their victims.

Based on the opinion of the above it can be concluded that some including:

characteristics about the Act of bullying,

a. existence of cat aggression behavior that pleases the perpetrator to hurthis victim.

b. The existence of an imbalance of power between the perpetrator and the victim.

c. The action was carried out not in balance giving rise to feelings of distress the victim.

$\mathrm{d}$. That behavior is performed repeatedly or continuously.

\section{The characteristics of perpetrators of Bullying}

According to Retno Ponny Astuti (2008:55) some characteristics of perpetrators of bullying, among other things:

Live in groups and master the social life of students at school.

a) Put yourself in a standstill in the school or its surroundings.

b) Is a popular student in school.

c) The gestures can often be marked; often walk in front,

d) intentionally bumping, saying rude, insulting or harassing.

e) The same thing expressed by the figures above, according to Andri Priyatna (2010: 6) mentions some characteristics of the perpetrators of bullying, as follows:

a. Like to hang out with children who used to bullying.

b. Hang out with children who like acts of violence.

c. Lack of warmth and low level of care for parents towards their children. d. Aggressive children who come from high social status can be perpetrators of bullying in order to get an award from their peers.

\section{Characteristics of Victims of Bullying}

a) From the above terms it can be concluded that the victim of bullying has

b) physical weakness; feeling worried, weak, sensitive and reserved; when in

c) attacked by perpetrators of bullying, usually the victim's reaction is to cry and

d) withdraw; inferiority; be alone and ostracized at school; long-term effects cause victims to be individual and inferior. Furthermore, according to the Sejiwa Amini Foundation (2008: 17) bullying is not possible only with the perpetrators of bullying. There must be victims who have been subjected to mistreatment and persecution. Some of the characteristics that can be victims of bullying include: (a) physically small and weak, (b) difficult to get along,

e) (c) children who have different accents, (d) look different than usual, (e) students who have low self-confidence

f) Similar with the characteristics of victims of bullying expressed by the figures above, according to Ponny Retno Astuti (2008: 55) characteristics of victims

g) bullying include:

a) Shy, reserved and loner

b) Suddenly become a loner or reserved

c) Often absent from school for unclear reasons

d) Behave strangely or unusual (fear / anger for no reason, scribbling, and so on).

\section{Understanding of Health}

\section{Definition of Mental Health}

Mental health is the ability to adjust to yourself, with others with the community and the environment in which he lives.

This definition is broader and general, because it is associated with life as a whole. The ability to adapt will bring people to the enjoyment of life and avoid anxiety, anxiety, and dissatisfaction. Besides that he is full of enthusiasm in life. To be 
able to adjust to ourselves, we must first know ourselves and accept as they are, then act according to our abilities and shortcomings. We must know and understand other people objectively, and not see others subjectively that is according to our feelings and measurements, but try to see people with the measurements of those people themselves.

According to this second definition, a mentally healthy person is someone who can master all the factors in his life, so he can avoid the pressures of feelings or things that bring frustration.

There is another definition of mental health, namely mental health is knowledge and actions that aim to develop and utilize all the potentials, talents, and dispositions that exist as much as possible, so as to bring happiness to yourself and others; and avoid mental disorders and diseases

This definition encourages people to develop and exploit all the potential that exists. There must be no talent that does not grow well, or which is used in a way that does not bring happiness, which interferes with the rights and interests of others. Talent that can not grow and develop properly, will lead to inner anxiety and conflict. It may also be that people have the opportunity to develop their talents and potential well, but their intelligence and intelligence are used to deceive, take the rights of others, or afflict people with the slander they have made. So even that person including people who are less healthy.

The final definition of mental health is the realization of a truly harmony between the functions of the soul, and having the ability to deal with ordinary problems that occur, and feel positively his happiness and ability.

The functions of the soul such as thoughts, feelings, attitudes of the soul, views and beliefs of life, must help each other and cooperate with each other, so that it can be said of harmony, which keeps people from feeling doubtful and doubtful, and avoiding anxiety and inner conflict (conflict) ).
It can be said that mental health is the avoidance of a person from the symptoms of disorders and mental illness, adjusting, can utilize all the potentials and talents that are as possible as possible and bring happiness together and the harmony of the soul in life. Keep in mind that mental health is relative, where perfect harmony between all bodily functions is there. What can be known is how far a person is away from normal mental health.

\section{The Scope of Mental Health}

Mental health experts set limits that the scope of mental health is (1) maintenance and promotion of mental health of individuals and the community, (2) prevention and supply of mental illness and damage. Moeljono and Latipun (1999) in broad outline the scope of mental health work includes the following matters:

a. Promotion of mental health, namely efforts to improve mental health. This effort is carried out departing from the view that mental health is qualitative-continuum and can be improved to the optimum extent.

b. Primary prevention, is a mental health effort to prevent disorders and mental illness. This effort was made so that disturbances and mental illness did not occur.

c. Secondary prevention, is a mental health effort to find cases early and early treatment of disorders and mental illness. This effort was made to reduce the duration of the disturbance and prevent a person from being defective.

d. Tertiary Prevention is an initial rehabilitation effort that can be carried out for people with mental health disorders. This effort was made to prevent disability or disability, not to experience disability that is permanent disability (Caplan, 1963; Parlmutter, 1982).

\section{Identification of Bullying Behavior}

According to Marini, Spear and Bombay (1999) proposed a model called the Multidimensional Buli Behavior Assessment Model. This model can help determine and identify bladder behavior. This model has three important components that comprehensively focus on the phenomenon of bladder. These components are; (1) five features 
of the definition of bladder behavior, (2) four specific types of bladder behavior, (3) three main groups involved in bullying behaviorBullying Behavior namely;

The difference in power between the bully and the victim of the bladder, (2) the repetitive patterns of aggressive behavior, (3) the tendency to control and harm, (4) the formation of an atmosphere of anxiety, threat, coercion and fear, (5) tendency to keep secret or hide Bullying behavior

Ponny Retno Astuti (2008: 11) explained that the impact of bullying on the victim is a feeling of pressure because the perpetrator controlled the victim. For the victim, this condition causes him to experience physical and psychological pain, self-esteem (self-esteem) which decreases, shame, trauma, unable to strike back, feel alone, awry, afraid of school (school phobia), where he feels nothing is help in the next condition is determined that the victim then alienates himself from school, or suffers from social fear (social phobia), and even tends to commit suicide.

According to Andri Priyatna (2010: 4) mentioned several adverse effects that can occur in children who are victims of bullying, including: (a) anxiety; (b) feeling lonely; (c) low self-esteem; (d) a low level of social competence; (e) depression; (f) psychosomatic symptoms; (g) social withdrawal; (h) running away from home; (i) consumption of alcohol and illegal drugs; (j) suicide; (k) decline in academic performance.

\section{Social Intervention Program}

There are many models and ways to deal with Bullying behavior. To deal with or overcome the occurrence of bullying can be done through a number of techniques or ways. According to Ponny Retno Astuti (2008: 25) there are three models of bullying prevention that can overcome bullying, namely:

\section{Transtory Model (Trastheoretical Model / TTM)}

The Transteori Model is one of the methods for raising awareness of the dangers of bullying which is solicitous, easy to understand, gradual but relatively fast and safe, for parents, teachers or children, victims and perpetrators. In each stage there is always a sense of curiosity, desire and greater effort to reach a higher level of knowledge.

\section{Network support}

The support network is functioning to help with the course of the transteori stages. Support network is a program to make communication efforts between the school and its community. In an effort to prevent bullying, the support network needs to be done first, namely by gathering together the entire school community to unite their understanding and involvement together.

\section{Friends program}

Companions program with the basic values of love, harmony, kindness, and responsibility are examples of programs that contain the most basic social values that facilitate the two models above can be implemented in a real, controlled, individual or group / together, organized and effective in preventing bullying through training to improve children's behavior.

\section{The Citizens Responsibility Program Recovery Model}

The recovery approach is an intervention process that gives the coach a clear picture that bladder behavior is behavior that cannot be allowed to apply in school. This approach reintegrates students who have made mistakes into the school community to become students who have endurance, and become members of the school community who are obedient and adhere to the rules and values that apply. In this intervention, counselors, victims and community students (peers) are brought together into the intervention program.

The CRP program (the program of responsible citizens) has a major value that is emphasized respect, consideration and participation. This intervention program outlines five principles, i.e. Expect the best from others. This principle asserts 
that the bullying and the bullying are behaviors that can be changed. Responsibility is behavior and feelings. This principle asserts that handling bladder behavior requires action, and should not involve scolding or reproaching someone as an individual

Acknowledge, accept the feelings and damage that has been done. This principle confirms that injury or damage resulting from bladder behavior needs to be accepted

Repair damage or destruction that has been done. This principle confirms that the damage and destruction that have been done need to be redeemed.

\section{Conclusion}

The school environment is a place for students to play and study. At the time in the school environment many events were encountered such as encouraging friends, seizing friends' toys, making fun of or mocking, these events seemed ordinary because they were common. But it was not realized, the practice of bullying had occurred. Mocking and mocking behavior can be categorized as verbal bullying behavior, whereas for physical bullying, such as forced pushing, slapping. Caring about other people. This principle confirms that educators and bladder victims are valued members of the school community. Support from others needs to be increased through participation in the school community, which is always caring and caring

Requires collaboration between management, schools, student teachers, parents and school support employees to develop effective strategies, policies and programs to stimulate success and security for all students. Tell the offender to stop the behavior immediately. Provide assistance to child victims of bullying to reduce the psychological impact caused.

\section{Daftar Rujukan}

[1] Andri Priyatna. (2010). Let's End Bullying: Memahami, Mencegah, dan Mengatasi
[2] Bullying. Jakarta: PT Elex Koputindo.

[3] Arya,L.(2018).Melawan Bullying, Menggagas Kurikulum Anti Bullying di Sekolah.

[4] Mojokerto: Sepilar Publising House.

[5] Ardiana Gashi \& Nikica MojsoskaBlazevski.European Journal of Education, Vol. 51, No. 3, 2016 DOI: 10.1111/ejed.12181 The Determinants of Students' Well-being in Secondary Vocational Schools in Kosovo and Macedonia

[6] Astuti, P.A.2008.Meredam Bullying; 3 Cara Efektif mengatasi K.P.A. Jakarta: PT.Grasindo

[7] Christhoponus Argo Widiharto, dkk. (2001). Perilaku Bullying Ditinjau dari Harga Diri dan Pemahaman Moral Anak. Skripsi. FKIP UNS

[8] Coloroso, B. (2003).Stop Bullying. Terjemahan The Bully, The Bullied, and TheBystander. Jakarta: PT Serambi Ilmu Semesta

[9] Corey, G. (2009). Teori dan Praktek Konseling \& Psikoterapi. Bandung: PT Refika Aditama.

[10] Daradjat. Z, 1996. Kesehatan Mental , P.T. Gunung Agung. Jakarta

[11] Djam`an. 1975.Islam Dan Psikosomatik ( penyakit Jiwa ).Penerbit Bulan Bintang. Jakarta

[12] DeependraKajiThapaID*, Denis VisentinID, Rachel Kornhaber, Michelle Cleary. Migration of adult children and mental health of older parents 'left behind': An integrative review; PLOS ONE https://doi.org/10.1371/journal.pone.02056 65 October 22, 2018

[13] Gabriela Ilie1*, Robert E. Mann2,4, Angela Boak2, Edward M. Adlaf2,3, Hayley Hamilton2,3, Mark Asbridge4, Ju "rgen Rehm2,3, Michael D. Cusimano1, Suicidality, Bullying and Other Conduct and Mental Health Correlates of Traumatic Brain Injury in Adolescents. PLOS ONE | www.plosone.org 1 April 2014 | Volume 9 | Issue 4 | e94936 
[14] Hawari. D, 1997. Al Qur`an , P.T. Dana Bhakti Prima Yasa. Yogyakarta

[15] Hansen HH, Hasselg å rd CE, Undheim AM, Indredavik MS. Bullying behaviour among Norwegian adolescents: Psychiatric diagnoses and school well-being in a clinical sample. Nord J Psychiatry 2014;68:355-361.

[16] Ingunn Marie Eriksen. The power of the word: students' and school staff's use of the established bullying definition. Educational REsEaRch, 2018 https://doi.org/10.1080/00131881.2018.14 54263

[17] Ken Rigby, PhD1. Consequences of Bullying in Schools; Can J Psychiatry, Vol 48, No 9, October 2003

[18] Meli Apriani .(2011). Upaya Peningkatan Kemampuan Berbicara di Depan Umum Melalui Teknik Sosiodrama Pada Siswa SMA N 11 Yogyakarta. Skripsi.FIP UNY.

[19] Mappiare-AT, Andi,2012.Tipe-tipe Metode Riset Kualitatif untuk Eksplanasi sosial Budaya dan Bimbingan Konseling.Malang: Penerbit Elang Emas bersama Prodi Bimbingan dan Konseling Fak. Ilmu pendidikan Universitas Negeri malang.

[20] Mulianai.H,Pereira. R, (2018). Why Children Bully? .Jakarta. Pt.Grasindo

[21] Moeljono N. \& Latipun. 1999. Kesehatan Mental, UMM Press. Malang

[22] PonnyRetnoAstuti. (2008). Meredam Bullying: $\quad 3$ Cara EfektifMenanggulangiKekerasanPadaAna $k$. Jakarta: PT Grasindo.

[23] Supratiknya. 1995. Mengenai Perilaku Abnormal, Penerbit Kanisius. Yogyakarta

[24] TehseenNazir , Falak Nesheen , Impact of school bullying on psychological wellbeing of adolescents; Indian Journal of Health and Wellbeing 2015, 6(10), 10371040 http://www.iahrw.com/index.php/home/jo urnal_detail/19\#list

[25] Tidjan, dkk. (2000). Bimbingan dan Konseling Sekolah Menengah. Yogyakarta:UNY Press.
[26] Tohirin. (2007). Bimbingan dan Konseling di Sekolah dan Madrasah (berbasisintegrasi). Jakarta: PT Raja Grafindo Persada.

[27] Oyaziwo Aluedse Ambrose Alii University; Bullying in Schools: A Form of Child Abuse in Schools .Vol. 30.1 isJducational i\&search $\mathrm{ki}^{\wedge}$ uarterly 37

[28] Wiyani.N.A. ( 2014). Save Our Children From School Bullying. Jogjakarta. ARRuzz Media.

[29] Yiqin Pan1 ๑, Hongyun Liu1,2 ๑, Puiyi Lau3, Fang Luo1,2*. PLOS ONE $\mid$ A latent transition analysis of bullying and victimization in Chinese primary school students

https://doi.org/10.1371/journal.pone.01828 02 August 24, 2017.

[30] Yayasan Sejiwa Amini. (2008). Bullying Mengatasi Kekerasan di Sekolah danLingkungan Sekitar Anak. Jakarta: PT Grasindo. 